\title{
SENTRA PENEGAKAN HUKUM TERPADU DALAM KONSEP SISTEM PERADILAN PIDANA PEMILU
}

\author{
Handoko Alfiantoro \\ Kejaksaan Negeri Situbondo, Jalan Basuki Rahmat 1A Situbondo Jawa Timur \\ handokoalfiantoro@yahoo.co.id
}

\begin{abstract}
The Center of Integrated Law Enforcement which is known as the "Sentra Gakkumdu" is a concrete manifestation of escort and supervision of the implementation of the General Election. The handling of alleged election crime violations has different work procedures, procedural law, and time limits, so that a one-stop handling pattern is established through Sentra Gakkumdu, which consists of elements of the Election Supervisory Body (Bawaslu), the Indonesian National Police and the Indonesian Attorney's Office. Based on the different handling patterns in the Gakkumdu Center, it should be included in a stronger legal basis through special legislation regarding the Election Criminal Justice System, which regulates formal law and material law, and regulates the expansion of the Integrated Criminal Justice System consists of components of Sentra Gakkumdu, components of the Judiciary Institution, and components of the Penal Institution. This aims to accelerate the interconnection between individuals and institutions in the handling of alleged election crime violations in a more comprehensive manner. This article is prepared using normative juridical research methods through the Statute Approach, Comparative Approach, and Conceptual Approach, which aims to critically examine the work patterns of the Sentra Gakkumdu as a way to the Concept of the Election Criminal Justice System.
\end{abstract}

Keywords: the General Election, the Center of Integrated Law Enforcement, legislation, Ilection Criminal Justice System Concept 


\begin{abstract}
Abstrak
Sentra Penegakan Hukum Terpadu yang familiar disebut dengan "Sentra Gakkumdu"merupakan wujud konkrit pengawalan dan pengawasan terhadap pelaksanaan Pemilu. Penanganan dugaan pelanggaran tindak pidana pemilu mempunyai tata kerja, hukum acara, dan limit waktu yang berbeda, sehingga dibentuk pola penanganan dalam satu atap melalui Sentra Gakkumdu, yang terdiri dari Unsur Badan Pengawas Pemilu (Bawaslu), Kepolisian RI, dan Kejaksaan RI. Berdasarkan pola penanganan yang berbeda dalam Sentra Gakkumdu tersebut sudah selayaknya diwadahi dalam sebuah dasar hukum yang lebih kuat melalui Peraturan Perundang-undangan khusus tentang Sistem Peradilan Pidana Pemilu, yang di dalamnya mengatur tentang hukum formil dan hukum materiil, serta mengatur tentang perluasan Sistem Peradilan Pidana Terpadu terdiri dari komponen Sentra Gakkumdu, komponen Lembaga Peradilan, dan komponen Lembaga Pemasyarakatan. $\mathrm{Hal}$ ini bertujuan untuk mempercepat interkoneksi antar personal dan lembaga dalam penanganan dugaan pelanggaran tindak pidana pemilu secara lebih komprehensif. Artikel ini disusun dengan menggunakan metode penelitian yuridis normatif melalui Pendekatan Undang-undang, Pendekatan Perbandingandan Pendekatan Konseptual, yang bertujuan untuk mengkaji secara kritis pola kerja Sentra Gakkumdu sebagai jalan menuju Konsep Sistem Peradilan Pidana Pemilu.
\end{abstract}

Kata Kunci: Pemilihan Umum, Sentra Penegakan Hukum Terpadu, Peraturan Perundangundangan, Konsep Sistem Peradilan Pidana Pemilu

\section{Pendahuluan}

Indonesia adalah negara hukum (rechstaat), bukan atas negara kekuasaan belaka (machstaat), sehingga semua hal harus didasarkan atas hukum. Adapun ciri-ciri negara hukum antara lain adanya perlindungan terhadap Hak Asasi Manusia, adanya supremasi hukum, pemisahan dan pembagian kekuasaan negara, dan peradilan yang bebas (Rosyada, 2000).

Pemisahan dan pembagian kekuasaan negara sebagai salah satu ciri negara hukum tersebut adalah manifestasi dari teori kedaulatan rakyat seperti yang dicetuskan oleh para penganut ajaran hukum alam seperti John Locke, JJ Rousseau, Montesque, dan Imanuel Kant yang secara umum menyatakan bahwa kekuasaan perlu dibatasi dengan cara membagi atau memisahkan kekuasaan negara menjadi legislative, exekutive, dan jucial atau yang populer dikenal dengan teori trias politica (Hufron \& Hadi2015).

Pembatasan kekuasaan dan kewenangan lembaga trias politica harus dilakukan secara seimbang dan saling monitoring (checks and balances), serta memberikan jaminan yang cukup luas dalam arti penghormatan (to respect), perlindungan (to protect), dan pemenuhan (to fulfill) Hak Asasi 
Manusia dan Hak Warga Negara, yang dalam perkembangannya pembatasan kekuasaan tersebut mengalami varian konsepsi salah satunya adalah dengan adanya pemilihan umum. (Fajar, 2006).

Pemilihan umum (pemilu) di Indonesia telahdilaksanakan secara demokratis dengan cara pemilihan langsung oleh rakyat terhadap wakilwakilnya baik dalam lembaga eksekutif maupun lembaga legislatif. Hal ini adalahbentuk aktualisasi dari bunyi Pasal 1 ayat (2) Undang-undang Dasar Negara Republik Indonesia Tahun 1945 yang menentukan bahwa kedaulatan berada di tangan rakyat dan dilaksanakan menurut Undang-Undang Dasar.

Dalam rangka pelaksanaan Pemilihan Umum (Pemilu) tersebut perlu diawasi, diantisipasi, dan diatur sedemikian rupa tentang jalan keluar terhadap adanya potensi-potensi permasalahan hukum Pemilu yang relatif beragam. Berdasarkan varian jenis pemilu yang diselenggarakan, telah ada masing-masing ketentuan yang mengaturnya,yang selanjutnya kami sebut dengan undang-undang pemilu, yaitu:

- UU RI Nomor 1 Tahun 2015 tentang Penetapan Perppu Nomor 1 Tahun 2014 tentang Pemilihan Gubernur, Bupati, dan Walikota menjadi Undang-Undang, sebagaimana telah diubah beberapa kali, terakhir dengan

- UU RI Nomor 10 Tahun 2016 tentang Perubahan Kedua Atas UU Nomor 1 Tahun 2015 tentang Penetapan Perppu Nomor 1 Tahun 2014 tentang Pemilihan Gubernur, Bupati, dan Walikota menjadi Undang-Undang;

- $\quad$ UU RI Nomor 7 Tahun 2017 tentang Pemlihan Umum, yang merupakan refleksi dari UU RI Nomor 42 Tahun
2008 tentang Pemilihan Umum Presiden dan Wakil Presiden, UU RI Nomor 8 Tahun 2012 tentang Pemilihan Umum Anggota DPRD, DPD, dan DPRD, serta UU RI Nomor 15 Tahun 2011 tentang Penyelenggaraan Pemilihan Umum.

Beragam potensi permasalahan hukum Pemilu telah nyata disebutkan dalam Bab XX UU RI Nomor 1 Tahun 2015 tentang Penetapan Perppu Nomor 1 Tahun 2014 tentang Pemilihan Gubernur, Bupati, dan Walikota,terdiri atas Pelanggaran Kode Etik Penyelenggara Pemilu, Pelanggaran Administrasi Pemilu, Sengketa Pemilu, Tindak Pidana Pemilu, Sengketa Tata Usaha Negara, atau pun Perselisihan Hasil Pemilu.

Kompleksitas potensi permasalahan hukum Pemilu tersebut akhirnya juga melibatkan banyak institusi dalam pola penanganannya, diantaranya: Dewan Kehormatan Penyelenggara Pemilu (DKPP), Komisi Pemilihan Umum (KPU), Badan Pengawas Pemilu (Bawaslu), Kepolisian RI, Kejaksaan RI, Pengadilan Negeri dan Pengadilan Tinggi, Pengadilan Tata Usaha Negara dan Pengadilan Tinggi Tata Usaha Negara, Mahkamah Agung, dan Mahkamah Konstitusi.

Tulisan ini hanya membatasi permasalahan hukum pemilu terkait dengan tindak pidana Pemilu,yang baik hukum pidana materiil atau pun hukum pidana formil-nya telah diatur secara khusus dalam undang-undang pemilu tersebut. Adapundalam pola penanganannya setidaknya melibatkan 5 (lima) institusi yaitu Badan Pengawas Pemilu (Bawaslu), Kepolisian, Kejaksaan, Pengadilan Negeri dan Pengadilan Tinggi.

Undang-undang pemilu tersebut sebenarnya bukan termasuk dalam 
jenis kategori undang-undang pidana secara murni, melainkan hanya berupa undang-undangadminisitrasi bersanksi pidana. Penggunaan hukum pidana dalam undang-undang pemilu tersebut semata-mata sebagai perwujudan untuk menegakkan norma dalam hukum administrasi tersebut.

Hukum acara pidana pemilu yang digunakan dalam undang-undang pemilu tersebutmempunyai beberapa bagian norma yang berbeda dengan hukum acara pidana induk yang ada dalam UU RI Nomor 8 Tahun 1981 tentang Hukum Acara Pidana (KUHAP). Perbedaan tersebut antara lain terletak pada komponen pelaksana, alur penanganan, dan batas waktunya.Namun demikian di sisi lain,hukum pidana formil yang digunakan dalam 2 (dua) undang-undang pemilu tersebut secara umum mempunyai materi muatan pengaturan yang sama antara yang satu dengan yang lainnya, sehingga keadaan inilahkemudian menimbulkan permasalahan tentang potensi duplikasi dan tingkat efektivitasnya.

Selanjutnya guna memperlancar interkoneksi antar personal dan lembaga yang menangani tindak pidana pemiliu dalam ranah eksekutif, maka dibentuklah Sentra Penegakan Hukum Terpadu yang familiar disebut dengan Sentra Gakkumdu, yang terdiri dari Unsur Badan Pengawas Pemilu (Bawaslu), Kepolisian, dan Kejaksaan.

Sentra Gakkumdu merupakan wujud konkrit pengawalan dan pengawasan terhadap pelaksanaan Pemilu dalam tahap awal. Secara sepintas unsur pelaksanaSentra Gakkmudu ini mirip dengan Komisi Pemberantasan Korupsi (KPK) yang didalamnya terdapat unsur
Penyidik dan Jaksa Penuntut Umum dalam satu atap, hanya perbedaannya dalam Sentra Gakkumdu ditambah lagi dengan unsur penyelenggara pemilu di dalamnya.

Pembentukan Sentra Gakkumdu ini tidak bisa lepas dari tujuan utamanya yaitu efektivitas kerja untuk menyamakan persepsi dan pemahaman dalam pola penanganan tindak pidana pemilu. Konsekuensi pembentukan Sentra Gakkumdu dalam penyelesaian tindak pidana pemilu tersebut pada hakikatnya telah memperluas komponen Sistem Peradilan Pidana Terpadu (Integrated Criminal Justice System) yang telah ada sebelumnya, sehingga secara lengkap komponen pelaksana dalam hukum acara pidana pemilu terdiri atas Badan Pengawas Pemiliu (Bawaslu), Kepolisian, danKejaksaan, yang tergabung dalam Sentra Gakkumdu, Pengadilan, dan Lembaga Pemasyarakatan, serta Advokat/ pengacara sebagai penyeimbang dan faktor pendorong (impetus majority).

Selanjutnya secara tegas undangundang pemilu telah mendelegasikan pengaturan lebih lanjut terkait dengan Sentra Gakkumdu dalam sebuah Peraturan Bersama antara Kepala Kepolisian Negara Republik Indonesia, Jaksa Agung Republik Indonesia, dan Ketua Bawaslu, sehingga atas dasar tersebut saat ini telah dikeluarkan Peraturan Bersama Ketua Badan Pengawas Pemilihan Umum Republik Indonesia, Kepala Kepolisian Republik Indonesia, dan Jaksa Agung Republik Indonesia, Nomor 14 Tahun 2016, Nomor 01 Tahun 2016, Nomor 013/ JA/11/2016 tentang Sentra Penegakan Hukum Terpadu pada Pemilihan Gubernur dan Wakil Gubernur, Bupati dan Wakil 
Bupati, serta Walikota dan Wakil Walikota. Selain itu juga telah diterbitkan Peraturan Bawaslu Nomor 9 Tahun 2018 tentang Sentra Gakkumdu yang secara umum mempunyai materi muatan pengaturan yang relatif sama dengan ketentuan yang ada para peraturan bersama tersebut.

Pada dasarnya anggota Sentra Gakkumdu ditambah dengan anggota sistem peradilan pidana yang lain telah membentuk konsep sistem peradilan pidana baru yakni Sistem Peradilan Pidana Pemilu.Akan tetapi turunan pengaturan lebih lanjut mengenai Sentra Gakkumdu yang hanya melalui Peraturan Bersama dan Peraturan Bawaslu, dinilai tidak terlalu kuat secara hierarki peraturan perundang-undangan, sehingga atas beberapa permasalahan tersebut di atas penulis tertarik untuk mengkaji lebih lanjut dalam sebuah tulisan berjudul Sentra Penegakan Hukum Terpadu Dalam Konsep Sistem Peradilan Pidana Pemilu.

\section{Metode penelitian}

Metode penelitian yang digunakan dalam tulisan ini menggunakan tipe penelitian yuridis normatif, dengan pendekatan masalah yang digunakan melalui pendekatan undang-undang (statute approach), pendekatan perbandingan (comparative approach), dan pendekatan konseptual (conceptual approach). Adapun sumber bahan hukum yang dipakai adalah sumber bahan hukum primair berupa peraturan perundangundangan terkait, bahan hukum sekunder berupa buku-buku tentang hukum, dan bahan non hukum berupa buku-buku diluar hukum. Terkait dengan metode analisis bahan hukum yang digunakan dalam tulisan ini menggunakan metode deduktif, yaitu berpangkal dari prinsip-prinsip dasar kemudian menghadirkan objek yang hendak diteliti, dengan kata lain, berpangkal dari prinsipprinsip umum menuju prinsip-prinsip khusus (Marzuki, 2011).

\section{Perspektif Teori}

\subsection{Tindak Pidana Pemilu}

Pada dasarnya istilah tindak pidana pemilu mempunyai terminologi yang sama dan merupakan bagian dari pengertian tindak pidana secara umum. Tindak pidana berasal dari suatu istilah dalam hukum belanda yaitu strafbarfeit. Ada pula yang mengistilahkan menjadi delict yang berasal dari bahasa latin delictum. Simons menerangkan bahwa strafbarfeit adalah adalah perbuatan atau tindakan yang diancam dengan pidana oleh undang-undang, bertentangan dengan hukum dan dilakukan oleh orang yang mampu bertanggung jawab (Hamzah, 1994).

Pengertian istilah tindak pidana Pemilu merupakan spesifikasi dari pengertian tindak pidana secara umum, yang berarti perbuatan tersebut hanya terkait dengan perbuatan pidana yang terjadi dalam penyelenggaraan pemilu, atau berhubungan dengan pelaksanaan tahapan-tahapan Pemilu, sebagai bentuk perbuatan melawan hukum terhadap undang-undang pemilu. Adapun secara singkat juga dapat dipahami jika tindak pidana pemilu adalah pelanggaran terhadap suatu kewajiban, hal mana pelanggaran tersebut diancam sanksi pidana dalam undang-undang pemilu (Santoso Dkk. 2006).

Terkait dengan jenisnya, tindak pidana pemilu terdiri atas kejahatan dan pelanggaran, yang telah diatur secara terinci dalam Pasal 117 sampai 
dengan Pasal 198A UU RI Nomor 1 Tahun 2015 tentang Penetapan Perppu Nomor 1 Tahun 2014 tentang Pemilihan Gubernur, Bupati, dan Walikota menjadi Undang-Undang, sebagaimana telah diubah beberapa kali, terakhir dengan UU RI Nomor 10 Tahun 2016 tentang Perubahan Kedua Atas UU Nomor 1 Tahun 2015 tentang Penetapan Perppu Nomor 1 Tahun 2014 tentang Pemilihan Gubernur, Bupati, dan Walikota menjadi Undang-Undang, dan juga dalam Pasal 488 sampai dengan Pasal 554 UU RI Nomor 7 Tahun 2017 tentang Pemilihan Umum.

\subsection{Penegakan Hukum Tindak Pidana Pemilu}

Penegakan hukum merupakan suatu usaha untuk mewujudkan ide-ide tentang kepastian hukum, kemanfaatan sosial dan keadilan menjadi kenyataan. Proses perwujudan ide-ide itulah yang merupakan hakikat dari penegakan hukum (Raharjo, 2005).

Penegakan hukum adalah sebuah tugas aparat penegak hukum, dan karena tugas, maka merupakan kewajiban kategoris dan kewajiban mutlak, sehingga. tidak mengenal istilah dengan syarat. Tugas adalah tugas, wajib dilaksanakan (Tanya, 2001).

Upaya penegakan hukum dalam ranah hukum pidana berjalan dalam sebuah sistem yang disebut dengan sistem peradilan pidana (criminal justice system). Istilah tersebutuntuk menunjukkan mekanisme kerja dalam penanggulangan kejahatan dengan mempergunakan dasar pendekatan sistem.Sistem peradilan pidana yang disebut juga dengan criminal justice process dimulai dari proses penyelidikan/penyidikan, penuntutan, dan pemeriksaan di muka pengadilan, serta diakhiri dengan pelaksanaan pidana di lembaga pemasyarakatan (Atmasasmita, 1996).

Lebih Ianjut Muladi (1995) menyebutkan jika sistem peradilan pidana merupakan jaringan (network) peradilan yang menggunakan hukum pidana sebagai sarana utamanya, baik hukum pidana materiil, hukum pidana formil, maupun hukum pelaksanaan pidana.

Sistem peradilan pidana secara umum, selalu melibatkan sub-sistem dalam ruang lingkup masing-masing yang dimulai dari institusi Kepolisian, Kejaksaan, Pengadilan, dan Lembaga Pemasyarakatan, serta Advokat/Pengacara sebagai penyeimbang (Anwar\&Adang, 2011).

\section{Gambar 1.}

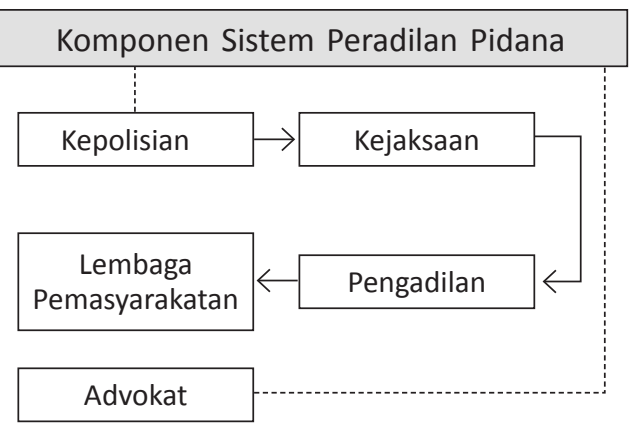

Sumber: KUHAP

Sementara dalam rangka penegakan hukum tindak pidana pemilu, sesuai dengan ketentuan undang-undang pemilu, selain sub-sistem yang telah disebutkan di atas maka disisipkan pula institusi penyelenggara pemilu yaitu Badan Pengawas Pemilu (Bawaslu) sebagai salah satu bagian sub-sistem tersebut.

Atas dasar tersebut pola penanganannya pun berubah yang 
awalnya dimulai oleh Kepolisian sebagai penerima laporan atau pun aduan, menjadi Badan Pengawas Pemilu (Bawaslu) sebagai titik awal penerima laporan atau pun temuan,sebagaimana dapat digambarkan sebagai berikut:

Gambar 2.

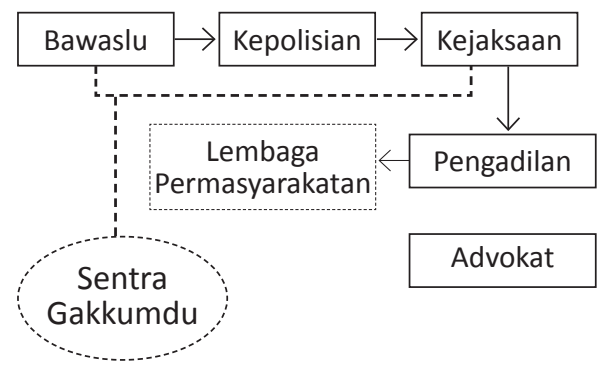

Sumber: KUHAP, UU Pemilu, Peraturan Bersama Ketua Bawaslu, Kapolri, Jaksa Agung, dan Perbawaslu

Berdasarkan hal tersebut terlihat jika telah ada varian perubahan komponen dan alur kerja dalam rangkaian sistem peradilan pidana secara umum, yang mana dalam sistem peradilan pidana pada tindak pidana pemilu, terdapat sebuah sistem lagi yang terintegrasi dalam satu jaringan terikat berupa Sentra Gakkumdu yang tersistempada ranah laporan / temuan, penyelidikan / penyidikan, penuntutan, dan eksekusi.

\section{Hasil dan Pembahasan}

\subsection{Kekhususan dalam Penegakan Hukum Tindak Pidana Pemilu}

Pemberlakuan undang-undang pemilu telah berimplikasi besar dalammenggeser beberapa substansi penting dalam pola penegakan hukum tindak pidanasecara umum. Kekhususan penegakan hukum tindak pidana pemilu setidaknya dapat terlihat dari 3 (tiga) aspek penting, yaitu aspek hukum pidana materiil, aspek hukum pidana formil, danaspek komponen pelaksana.

\section{- Aspek hukum pidana materiil}

Hukum pidana materiil memuat aturan-aturan yang menetapkan atau merumuskan perbuatan yang dapat dipidana, syarat-syarat untuk dapat dijatuhi pidana, dan ketentuan mengenai sanksi pidananya.

Secara umum pengaturan hukum pidana materiil terdapat dalam buku kodifikasi Kitab Undang-Undang Hukum Pidana (KUHP).Namun demikian dalam perkembangannyaKUHP sudah tidak lagi dapat mengakomidasi seluruh ketentuan hukum pidana materiil yang berkembang dalam masyarakat, sehingga kemudian banyak sekali undang-undang diluar KUHP yang mengatur sendiri hukum pidana materiilnya sebagai bagian dari salah satu perwujudan asas lex specialis derogat legi generalidan asas lex posterior derogat legi priori.

Hal yang sama juga berlaku dalam undang-undang pemilu. Secara umum, karakter khas hukum pidana materiil dalam undang-undang pemilu dapat terlihat pada spesifikasi subjek hukumnya, modus operandi-nya, maupun sanksi pidananya.

Adapun ketentuan deliknya jugakhusus hanya dalam konteks pemilu saja, dengan varian delik yang substansinya benar-benar baruyang hanya ada di undang-undang pemilu, atau pun klausul yang merupakan refleksi dari substansi tindak pidana umum yang kemudian dijadikan sebagai delik pemilu, seperti dalam Pasal 179 UU RI Nomor 1 Tahun 2015 tentang Penetapan Perppu Nomor 1 Tahun 2014 tentang Pemilihan Gubernur, Bupati, dan Walikota menjadi Undang-Undang, berkaitan dengan 
pemalsuan surat yang merupakan refleksi dari ketentuan Pasal 263 KUHP.

\section{- Aspek hukum pidana formil}

Hukum pidana formil mengatur tentang pedoman para penegak hukum dalam melaksanakan ketentuan hukum pidana materiil, yang lebih dikenal dengan sebutan hukum acara pidana, yang secara umum diatur dalam Kitab Undang-Undang Hukum Acara Pidana (KUHAP).

Sejalan dengan hukum pidana materiil, dalam perkembangannya KUHAP tidak lagi dapat mengatur seluruh ketentuan hukum acara pidana bagi para penegak hukum, sehingga lagi-lagi banyak undang-undang yang mengatur sendiri sebagian hukum pidana formilnya termasuk dalam undang-undang pemilu.

Secara khusus ketentuan hukum acara pidana pada tindak pidana pemilu diatur dalam:

- Pasal 146 sampai dengan Pasal 151

UU RI Nomor 1 Tahun 2015 tentang Penetapan Perppu Nomor 1 Tahun 2014 tentang Pemilihan Gubernur, Bupati, dan Walikota menjadi UndangUndang, sebagaimana telah diubah beberapa kali, terakhir dengan UU RI Nomor 10 Tahun 2016 tentang Perubahan Kedua Atas UU Nomor 1 Tahun 2015 tentang Penetapan Perppu Nomor 1 Tahun 2014 tentang Pemilihan Gubernur, Bupati, dan Walikota menjadi Undang-Undang

- Pasal 476 sampai dengan Pasal 485UU RI Nomor 7 Tahun 2017 tentang Pemlihan Umum

- Pasal 12 sampai dengan Pasal 28 Peraturan Bersama antara Kepala Kepolisian Negara Republik Indonesia, Jaksa Agung Republik
Indonesia, dan Ketua Bawaslu, sehingga atas dasar tersebut saat ini telah dikeluarkan Peraturan Bersama Ketua Badan Pengawas Pemilihan Umum Republik Indonesia, Kepala Kepolisian Republik Indonesia, dan Jaksa Agung Republik Indonesia, Nomor 14 Tahun 2016, Nomor 01 Tahun 2016, Nomor 013/JA/11/2016 tentang Sentra Penegakan Hukum Terpadu pada Pemilihan Gubernur dan Wakil Gubernur, Bupati dan Wakil Bupati, serta Walikota dan Wakil Walikota;

- Pasal 18 sampai dengan Pasal 31 Peraturan Bawaslu RI Nomor 9 Tahun 2018 tentang Sentra Penegakan Hukum Terpadu;

Berdasarkan ketentuan yang ada dalam pasal-pasal tersebut di atas dapat dilihat karakter khusus dalam hukum pidana formil penanganan perkara tindak pidana pemilu sebagai berikut:

Batas waktu yang relatif singkat yaitu: Penyelidikan maksimal 5 (lima) hari, Penyidikan maksimal 14 (empat belas) hari, penelitian berkas oleh Jaksa Penuntut Umum maksimal 3 (tiga) hari, pengembalian berkas kembali dari penyidik kepada Jaksa Penuntut Umum maksimal 3 (tiga) hari, pelimpahan perkara kepada Pengadilan Negeri maksimal 5 (lima) hari, waktu sidang maksimal 7 (tujuh) hari, waktu banding dan memori banding maksimal 3 (tiga) hari, dan eksekusi maksimal 3 (tiga) hari;

- Secara tersirat tidak ada penghentian penyidikan, karena peluang penghentian terhadap laporan / temuan hanya ada saat tahap penyelidikan; 
- Tidak ada bolak-balik perkara antara Penyidik dengan Jaksa Penuntut Umum, karena pengembalian berkas perkara hanya dibatasi 1 (satu) kali saja. Pengembalian berkas perkara ini pun bisa jadi sangat akan jarang dilakukan karena dalam Sentra Gakkumdu sebelumnya sudah harus dibahas dan dipaparkan terlebih dahulu antara penyidik dan Jaksa Penuntut Umum;

- Tidak ada upaya hukum lagi setelah upaya hukum Banding;

\section{- Aspek komponen pelaksana}

Telah diketahui jika komponen pelaksana sistem peradilan pidana secara umum adalah Kepolisian, Kejaksaan, Pengadilan, dan Lembaga Pemasyarakatan, ditambah dengan advokat / pengacara. Namun demikian dalam sistem peradilan pidana pada tindak pidana pemilu ada 1 (satu) lagi komponen pelaksana yang disisipkan yaitu Bawaslu dari unsur penyelenggara pemilu.

Secara substansial pada pokoknya Bawaslu tidak memiliki kewenangan khusus dalam proses penyelidikan, penyidikan, penuntutan, dan eksekusi perkara tindak pidana pemilu. Akan tetapi penempatan Bawaslu sebagai pihak yang menerima laporan/temuan dugaan tindak pidana pemilu, serta adanya kewenangan Bawaslu untuk melakukan permintaan keterangan atau klarifikasi, serta penyertaan Bawaslu sebagai bagian dari Sentra Gakkumdu dalam tiap tahapan proses pidana pemilu membuat Bawaslu menjadi bagian yang tidak terpisahkan dari komponen pelaksana sistem peradilan pidana pada tindak pidana pemilu.
Selain itu kekhususan lain dari aspek komponen pelaksana juga terlihat pada hakim yang memeriksa dan mengadili perkara tindak pidana pemilu, yaitu adanya modifikasi berupa pembentukan Majelis Khusus sebagai majelis hakim yang menangani perkara tindak pidana pemilu dengan syarat dan kualifikasi tertentu berdasarkan Peraturan Mahkamah Agung. Kekhususan lain yang paling terlihat tentunya adanya titik temusebagai sistem jaringan yang saling berkaitan antara 3 (tiga) komponen pelaksana sistem peradilan pidana pada tindak pidana pemilu yaitu Bawaslu, Kepolisian, dan Kejaksaan dalam satu atap bernamaSentra Penegakan Hukum Terpadu (Gakkumdu).

\subsection{Sentra Gakkumdu dalam Konsep Sistem Peradilan Pidana Pemilu}

Sentra Gakkumdu mempunyai posisi yang sangat penting dalam penegakan hukum tindak pidana pemilu. Kegiatan Sentra Gakkumdu hampir mendominasi seluruh bagian dari alur sistem peradilan pidana pada tindak pidana pemilu.

Sejak dari tahap laporan/temuan, Sentra Gakkumdu telah bekerja dengan pimpinan awal adalah Bawaslu dengan dibantu dan didampingi Penyidik Kepolisian dan Jaksa. Kemudian dalam tahap penyelidikan / penyidikan Sentra Gakkumdu juga terikat satu sama lain dengan penggerak utama adalah Kepolisian dengan dimonitor oleh Jaksa dan Bawaslu. Selanjutnya pada tahap Penuntutan serta eksekusi, komando utama Sentra Gakkumdu beralih pada Kejaksaan dengan tembusan kepada penyidik Kepolisian dan Bawaslu. Sehingga dari awal sampai akhir alur penegakan hukum tindak pidana pemilu, 
Sentra Gakkumdu selalu berperan saling berkaitan satu sama lain dengan leading sector yang saling bergantian.

Sentra Gakkumdu adalah salah satu wujud konkrit pengawalan proses penyelenggaraan pemilu, yang merupakan integrasi dari lembaga penyelenggara pemilu, lembaga penyidikan, dan lembaga penuntutan yang bekerja dalam satu pola pikir dan kesamaan sikap. Hal tersebut tentunya memberikan peluang pola kerja yang lebih efektif dan efisien, meskipun nantinya memungkinkan monitoring antar lembaga dalam rangka checks and balancessecara resmi menjadi sedikit berkurang.

Secara umum posisi Sentra Gakkumdu dalam alur sistem peradilan pidana pada tindak pidana pemilu hampir mirip dengan posisi Komisi Pemberantasan Korupsi (KPK)dalam alur sistem peradilan pidana pada tindak pidana korupsi. Walaupun telah diketahui jika kedudukan hukum KPK jauh lebih kuat karena berwujud sebagai lembaga negara (Pasal 3 UU RI Nomor 30 Tahun 2002 tentang Komisi Pemberantasan Tindak Pidana Korupsi), dari pada Gakkumdu yang hanya sebagai sentra (pusat).
Gambar 3.

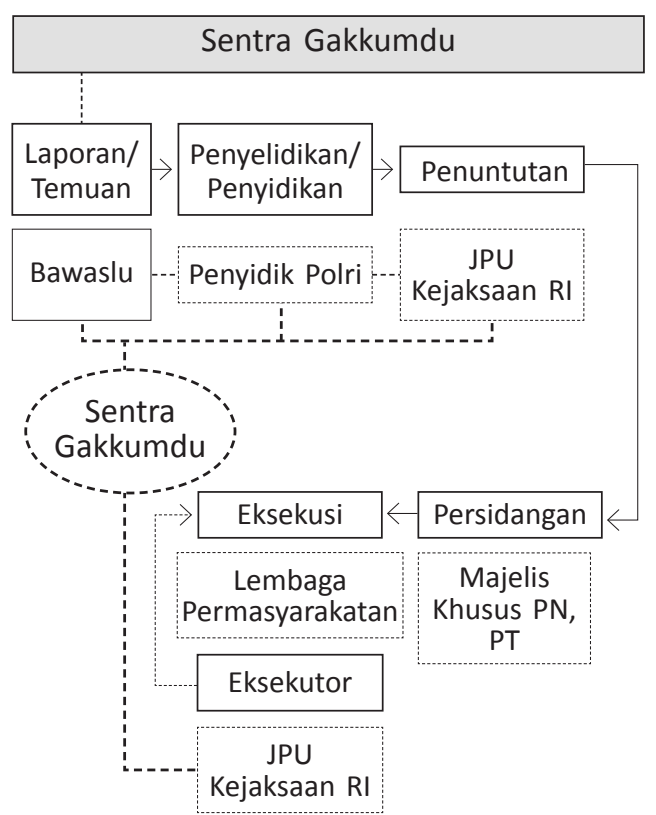

Sumber: KUHAP, UU Pemilu, Peraturan Bersama Ketua Bawaslu, Kapolri, Jaksa Agung, Perbawaslu

\section{Gambar 4.}

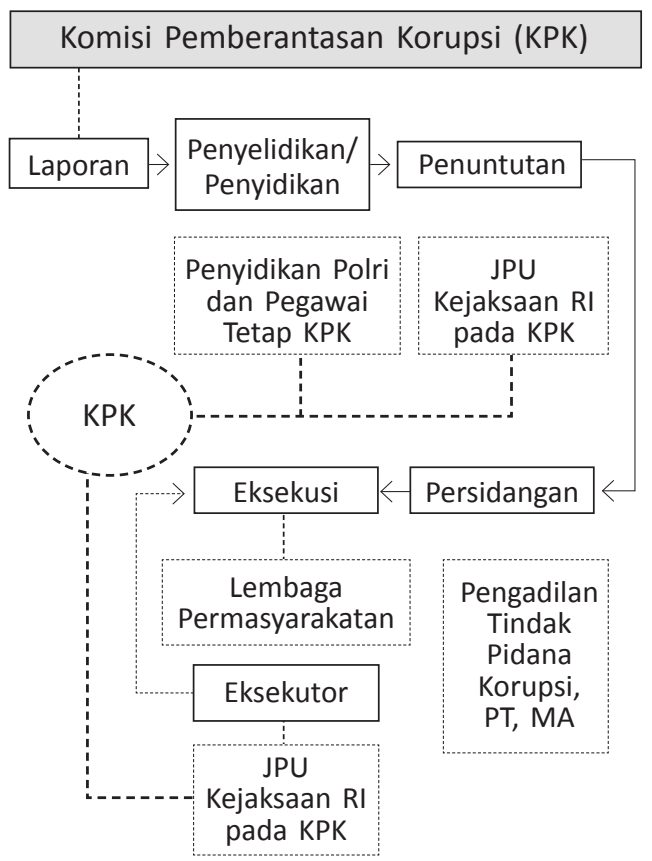

Sumber: KUHAP, UU KPK, UU Tipikor 
Hukum pidana formil yang ada dalam 2 (dua) undang-undang pemilu, tidak begitu menampakkan peran penting Sentra Gakkumdu. Undang-undang pemilu tersebut seolah-olah hanya mengatur hukum acara pidana terkait dengan percepatan batas waktu, dan perubahan tentang batas akhir kapan perkara pidana pemilu menjadi inkracht van gewijsde. Adapun terkait dengan kewenangan masing-masing unsur pelaksananya yaitu Bawaslu, Kepolisian, dan Kejaksaaan, hukum acara pidana pada undang-undang pemilu tersebut pun terkesan hanya mengaturnya secara parsial.

Bahkan pengaturan tentang Sentra Gakkumdu dalam undang-undang pemilu hanya ada dalam satu pasal yaitu Pasal 152 UU RI Nomor 1 Tahun 2015 tentang Penetapan Perppu Nomor 1 Tahun 2014 tentang Pemilihan Gubernur, Bupati, dan Walikota menjadi Undang-Undang, sebagaimana telah diubah beberapa kali, terakhir dengan UU RI Nomor 10 Tahun 2016 tentang Perubahan Kedua Atas UU Nomor 1 Tahun 2015 tentang Penetapan Perppu Nomor 1 Tahun 2014 tentang Pemilihan Gubernur, Bupati, dan Walikota menjadi Undang-Undang, dan dua pasal dalam Pasal 486-487 UU RI Nomor 7 Tahun 2017 tentang Pemilihan Umum.

Peran Bawaslu, Kepolisian, dan Kejaksaaan sebagai sebuah jaringan (network)dalam wadah Sentra Gakkumdu baru terlihat secara jelas dan tegas dalam Peraturan Bersama Ketua Badan Pengawas Pemilihan Umum Republik Indonesia, Kepala Kepolisian Republik Indonesia, dan

Jaksa Agung Republik Indonesia, Nomor 14 Tahun 2016, Nomor 01 Tahun 2016, Nomor 013/JA/11/2016 tentang Sentra Penegakan Hukum Terpadu pada Pemilihan Gubernur dan Wakil Gubernur,
Bupati dan Wakil Bupati, serta Walikota dan Wakil Walikota, dan dalam Peraturan Bawaslu Nomor 9 Tahun 2018 tentang Sentra Penegakan Hukum Terpadu.

Apabila dilihat sebenarnya pengaturan tersebut tidak sekedar tentang pola hubungan dan tata kerja Sentra Gakkumdu saja, tetapi juga telah menyentuh pada tataran hukum pidana formilnya, karena dalam klausul-klausul tersebut telah diatur secara tegas mekanisme penanganan tindak pidana pemilu yang menggeser beberapa ketentuan hukum acara pidana secara umum, selain itu kegiatan Sentra Gakkumdu juga telah membuka sekat batas resmi antara Penyidik dengan Jaksa Penuntut Umum.

Tabel 1. Kekhususan dan Sinergitas Sentra Gakkumdu Dalam Hukum Acara Pidana Pada Tindak Pidana Pemilu

\begin{tabular}{|l|l|}
\hline Dasar Hukum & \multicolumn{1}{|c|}{ Kegiatan } \\
\hline $\begin{array}{l}\text { Pasal } 15 \text { ayat } \\
\text { (1) s/d ayat } \\
(6)\end{array}$ & $\begin{array}{l}\text { Laporan/Temuan diterima } \\
\text { oleh Bawaslu didampingi } \\
\text { oleh Penyidik dan Jaksa }\end{array}$ \\
\hline Pasal 16 ayat \\
(1) & $\begin{array}{l}\text { Bawaslu, Penyidik, dan } \\
\text { Jaksa lakukan Pembahasan } \\
\text { Pertama dalam waktu } \\
\text { 1x24 jam setelah laporan/ } \\
\text { temuan }\end{array}$ \\
\hline Pasal 17 & $\begin{array}{l}\text { Bawaslu lakukan Kajian } \\
\text { Pelanggaran dengan } \\
\text { permintaan keterangan/ } \\
\text { klarifikasi yang didampingi } \\
\text { oleh Penyidik dan Jaksa }\end{array}$ \\
\hline Pasal 15 ayat & $\begin{array}{l}\text { Bawaslu mengeluarkan } \\
\text { Surat Perintah Tugas } \\
\text { (7) }\end{array}$ \\
$\begin{array}{l}\text { Sprint.Tug) untuk } \\
\text { melaksanakan } \\
\text { Penyelidikan }\end{array}$ \\
\hline Pasal 15 ayat & $\begin{array}{l}\text { Penyidik mengeluarkan } \\
\text { Surat Perintah } \\
\text { Penyelidikan (Sprint.Lid) }\end{array}$ \\
\hline Pasal 17 ayat & $\begin{array}{l}\text { Penyelidikan oleh Penyidik } \\
\text { Polri didampingi dan } \\
\text { dimonitor oleh Jaksa }\end{array}$ \\
\hline
\end{tabular}




\begin{tabular}{|c|c|}
\hline Pasal 19 & $\begin{array}{l}\text { Bawaslu, Penyidik, dan } \\
\text { Jaksa lakukan Pembahasan } \\
\text { Kedua terkait pemenuhan } \\
\text { unsur dalam waktu } \\
\text { maksimal } 5 \text { hari setelah } \\
\text { laporan/temuan. Apabila } \\
\text { memenuhi unsur maka } \\
\text { dilanjutkan ke tahap } \\
\text { penyidikan, apabila } \\
\text { tidak maka penanganan } \\
\text { laporan/temuan } \\
\text { dihentikan }\end{array}$ \\
\hline Pasal 20 & $\begin{array}{l}\text { Rapat Pleno peningkatan } \\
\text { penanganan perkara ke } \\
\text { tahap penyidikan, atau } \\
\text { pun perkara dihentikan }\end{array}$ \\
\hline $\begin{array}{l}\text { Pasal } 21 \text { ayat } \\
\text { (1) s/d ayat } \\
\text { (3) }\end{array}$ & $\begin{array}{l}\text { Penyidik mengeluarkan } \\
\text { Surat Perintah Penyidikan } \\
\text { (Sprint.Dik) dan Surat } \\
\text { Pemberitahuan Dimulainya } \\
\text { Penyidikan (SPDP) pada } \\
\text { hari bersamaan }\end{array}$ \\
\hline $\begin{array}{l}\text { Pasal } 21 \text { ayat } \\
\text { (4) }\end{array}$ & $\begin{array}{l}\text { Penyidikan maksimal } 14 \\
\text { hari sejak laporan/temuan }\end{array}$ \\
\hline $\begin{array}{l}\text { Pasal } 21 \text { ayat } \\
\text { (5) }\end{array}$ & $\begin{array}{l}\text { Penyidikan oleh Penyidik } \\
\text { Polri denga didampingi } \\
\text { dan dimonitor oleh Jaksa }\end{array}$ \\
\hline Pasal 22 & $\begin{array}{l}\text { Pembahasan ketiga } \\
\text { dihadiri oleh Penyidik, } \\
\text { Jaksa, dan Bawaslu, untuk } \\
\text { menghasilkan kesimpulan } \\
\text { pelimpahan kasus perkara } \\
\text { kepada Jaksa }\end{array}$ \\
\hline
\end{tabular}

Sumber: Peraturan Bersama Ketua Bawaslu, Kapolri, dan Jaksa Agung tentang Sentra Gakkumdu pada Pemilihan Gubernur dan Wakil Gubernur, Bupati dan Wakil Bupati, serta Walikota dan Wakil Walikota

Berdasarkan penjelasan di atas terlihat jika Sentra Gakkumdu berperan besar dalam penyelesaian tindak pidana pemilu. Sentra Gakkumdu terwujud sebagai mini sistem dalam sebuah sistem yang lebih besar berupa sistem peradilan pidana pada tindak pidana pemilu.
Keberadaan Sentra Gakkumdu sebagai komponen yang dipandang sebagai sebuah sistem telah memenuhi ciri-ciridari sistem itu sendiri yaitu:

- Ada bagian yang menjadi bagian dari sistem tersebut;

- Adanya interrelasi (keterkaitan), saling mempengaruhi bagian-bagian yang ada;

- Adanya suatu kesatuan yang terintegrasi yang membuat sebuah entitas (unik dan berbeda);

- Ada arah pencapaian sasaran tertentu;

- Tujuan yang memberi makna bagi keberadaan sistem tersebut (Nisjhar, 1997).

Namun demikian posisi sentral dan strategis yang dimiliki Sentra Gakkumdu sebagai sebuah sistem tidak diwadahi dengan dasar hukum yang lebih kuat secara hierarki peraturan perundangundangan. Hal ini karenaSentra Gakkumdu hanya didelegasikan oleh undang-undang pemilu kepada Peraturan Bersama Ketua Bawaslu, Kapolri, dan Jaksa Agung.

Konsekuensi pengaturan Sentra Gakkumdu yang hanya diatur dalam peraturan perundang-undangan setara sebuah "peraturan" sebagaimana ketentuan Pasal 8 ayat (1) UU RI Nomor 12 Tahun 2011 tentang Pembentukan Peraturan Perundang-undangan, dapat menimbulkan adanya potensi pengaturan yang berulang-ulang atau duplikasi dalam sebuah peraturan yang berbeda.

Hal ini bisa dilihat dalam Peraturan Bersama Ketua Badan Pengawas Pemilihan Umum Republik Indonesia, Kepala Kepolisian Republik Indonesia, dan Jaksa Agung Republik Indonesia, Nomor 14 Tahun 2016, Nomor 01 Tahun 2016, Nomor 013/JA/11/2016 tentang 
Sentra Penegakan Hukum Terpadu pada Pemilihan Gubernur dan Wakil Gubernur, Bupati dan Wakil Bupati, serta Walikota dan Wakil Walikota, dengan Peraturan Bawaslu Nomor 9 Tahun 2018 tentang Sentra Gakkumdu, sehingga keadaaan ini membuat efektivitas sebuah peraturan yang mengatur hukum acara pidana kurang berkepastian.

Secara substansial memang Pasal 8 ayat (2) UU RI Nomor 12 Tahun 2011 tentang Pembentukan Peraturan Perundang-undangan memberikan peluang tentang pendelegasian pengaturan tersebut. Akan tetapi materi muatan yang diatur dalam Peraturan Bersama Ketua Bawaslu, Kapolri, dan Jaksa Agung tahun 2016,serta Peraturan Bawaslu terbaru tahun 2018 khususnya dalam bab tentang tata hubungan dan pola kerja Sentra Gakkumdu pada hakikatnya adalah mengatur tentang Hukum Pidana Formil (Hukum Acara Pidana) dalam sebuah sistem peradilan pidana.

Berdasarkan uraian di atas sebagai bentuk penguatan dan apresiasi terhadap keberadaan Sentra Gakkumdu, yang kegiatannya mendominasi hampir seluruh kegiatan penegakan hukum tindak pidana pemilu di Indoensia, maka tidak berlebihan jika pengaturan tentang hukum acara pidana tentang pemiluyang melibatkan Sentra Gakkumdu diatur dalam sebuah peraturan perundangundangan yang setara dengan KUHAP berkonsepUndang-Undang tentang Sistem Peradilan Pidana Pemilu.

\section{Simpulan}

Pengaturan hukum pidana pemilu dan hukum acara pidana pemilu dalam 2 (dua) undang-undang pemilu yang berbeda dinilai kurang efektif dan berpotensi duplikasi. Kekhususan hukum acara pidana pemilu dalam undangundang pemilu tidak dicantumkan secara rinci tentang peran Sentra Gakkumdu dalam penegakan hukum pemilu, padahal apabila dilihat secara lebih komprehensif peran serta kedudukan Sentra Gakkumdu telah menggeser pola hukum acara pidana secara umum dan membentuk hukum acara pidana tersendiri tentang Pemilu.

Sentra Gakkumdu merupakan pusat aktivitas penegakan hukum tindak pidana Pemilu yang terbentuk di tingkat pusat, provinsi, kabupaten/kota, dan luar negeri, sehingga Sentra Gakkumdu hampir komplit ada pada setiap teritorial wilayah di Indonesia.

Sentra Gakkumdu mempunyai konsep efektivitas pola kerja yang cukup baik dengan menjadi sebuah mini sistem dalam sebuah sistem besar, serta menghapus sekat-sekat resmi antara penyelenggara pemilu dengan para penegak hukum dalam penanganan tindak pidana pemilu, sehingga Sentra Gakkumdu layak dijadikan sebagai role model penegakan hukum yang ideal (ideal law enforcment)masa kini.

Namun demikian dominasi Sentra Gakkumdu dalam penegakan hukum tindak pidana pemilu tidak sebanding dengan pengaturannya dalam hierarki peraturan perundang-undangan. Sehingga pengaturan Sentra Gakkumdu haruslah lebih diperkuat lagi tidak hanya dalam bentuk sebuah peraturan perundangundangan setara menteri atau pun lembaga/badan,melainkan lebih pada bentuk konsep undang-undang tentang Sistem Peradilan Pidana Pemilu. 


\section{DAFTAR PUSTAKA}

Anwar, Y. \& Adang. (2011). Sistem Peradilan Pidana: Konsep, Komponen,\&Pelaksanaannya dalam Penegakan Hukum di Indonesia. Bandung: Widya Padjadjaran.

Atmasasmita, R. (1996). Sistem Peradilan Pidana Indonesia (Criminal Justice System), Perspektif Eksistemsialisme dan Abolisionisme. Jakarta: Bina Cipta.

Fajar, A.M. (2006). Hukum Konstitusi dan Mahkamah Konstitusi. Jakarta: Konstitusi Press.

Hamzah, A. (1994). Asas-Asas Hukum Pidana. Jakarta: Rineka Cipta,

Hufron \& Hadi, S. (2015). Ilmu Negara Kontemporer (Telaah Teoritis Asal Mula, Tujuan, dan Fungsi Negara, Negara Hukum dan Negara Demokrasi. Yogyakarta: Laksbang Grafika dan Kantor Advokatn"Hufron\&Rubaie.

Muladi. (1995). Kapita Selekta Hukum Pidana. Semarang: Universitas Diponegoro.

Nisjhar, K. (1997). Teori Sistem dan Pendekatan Sistem dalam Bidang Manajemen. Bandung: CV Mandar Maju.

Raharjo, S. (2005). Masalah Penegakan Hukum Suatu Tinjauan Sosiologis. Bandung: Sinar Baru.

Rosyada, D. (2000). Pendidikan Kewarganegaraan Demokrasi, HAM, dan Masyarakat Madani. Jakarta: Puslit IAIN Syarif Hidayatullah.

Santoso, T. Dkk. (2006). Penegakan Hukum Pemilu, Praktik Pemilu 2004, Kajian Pemilu 2009-2014. Jakarta: Perkumpulan Untuk Pemilu dan Demokrasi.

Tanya, B.L. (2001). Penegakan Hukum dalam Terang Etika. Yogyakarta: Genta Publising. 